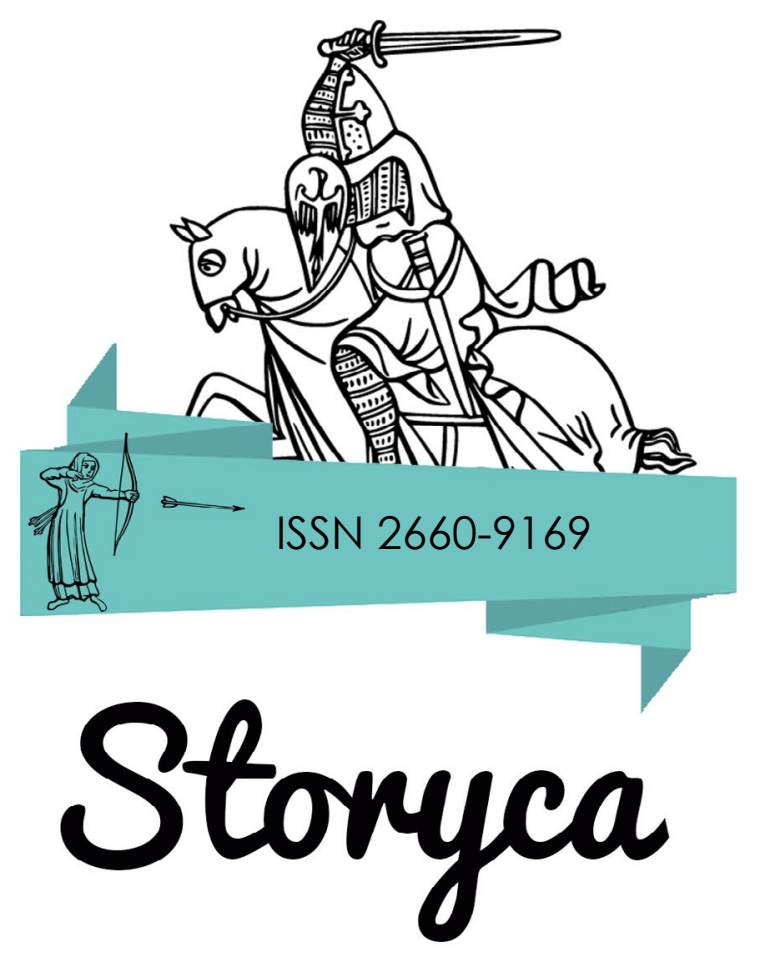

\title{
Imagens da Idade Média em Alexander Nevsky e Marketa Lazarová: algumas considerações estéticas e históricas
}

Joana Gomes

SMELS-IF/UP

Vitor Guerreiro

IF/UP

1. Introdução: A Idade Média como imagem

O uso artístico de representações da ldade Média como forma de pensar em questões levantadas pela própria época em que a representação é feita ou apresentada não é novo. Quando o optimismo universalista do projecto das Luzes, iniciado no século XVIII, esmorece na Europa oitocentista sob a emergência do imperialismo napoleónico e da revolução industrial, e a confiança irrestrita nos poderes da razão cede gradualmente ao culto do particular, das identidades nacionais e regionais, do mito e do misticismo, artistas como Caspar David Friedrich, Henry Fuseli e Delacroix, e escritores como Novalis, Kleist ou Walter Scott, para citar apenas alguns exemplos, começam a usar a recriação de 
lendas do passado mais remoto como modo de reflectirem e intervirem no seu presente. Na verdade, o próprio conceito de «ldade Média» surge da necessidade de a Renascença italiana falar de si mesma, reunindo sob essa designação mil anos de história da Europa, sendo o significado de «medieval» definido negativamente, pelo contraste com essa mesma realidade. Acresce a isto o facto de o conceito de «medieval» se revelar problemático quando desviamos o olhar para além da Europa, na medida em que a sua aplicação a outras culturas tem vindo a ser contestada como "eurocêntrica» (Baver, 2018). Por outro lado, mesmo no próprio contexto europeu, o conceito gera dificuldades, pois as características que se pretende descrever com a aplicação do conceito extravasam as balizas temporais convencionalmente aceites para o mesmo, revelando continuidades inesperadas (Getty, 2013; Le Goff, 2014). Trocando por miúdos: há na «modernidade» mais «medievalidade» do que os «modernos» esperariam encontrar.

Assim, num certo sentido, as representações artísticas da ldade Média são representações de uma representação. A «ldade Média» é, antes de mais, uma ideia, uma perspectiva, um modo de ver a realidade histórica contida num dado período cujas fronteiras não são claramente definidas, e não uma designação neutra para essa realidade histórica, embora hoje em dia a usemos como tal. $\bigcirc$ que distingue $O$ uso peculiarmente artístico destas representações é uma certa inversão valorativa relativamente às características que haviam sido associadas à ldade Média pelos intelectuais, filósofos, e políticos. A desilusão e a desconfiança perante os ideais de ciência, progresso e governo ruesclarecido» determinarão a apetência dos artistas e intelectuais por encontrar neste período uma fonte de inspiração e renovação da sua linguagem. Entretanto, o processo de emergência do estado-nação como entidade política não estará alheio a tais motivações, sendo o interesse pela Idade Média também impulsionado pelo desejo de encontrar fontes de identidade e legitimidade. Assim, a dicotomia entre representar / interpretar - mundo e transformá-lo revela-se falsa, porque vivemos num mundo parcialmente constituído por representações, e boa parte dos factos que esse mundo contém só são o que são em virtude de como os representamos. Vivemos enredados em representações que moldam as nossas vidas, e que, não menos teimosamente do que os seixos e as serras, não desaparecem se as ignorarmos. É precisamente neste terreno que se joga a dimensão política da arte, bem como a dimensão estética da política, e é também isto que pretendemos esclarecer com este ensaio.

Estas são, a traços muitíssimo largos, as balizas do contexto histórico, social e político em que o interesse nas representações da ldade Média surge. Porém, o problema que nos ocupa aqui é o do uso peculiar de representações cinematográficas da Idade Média, em contextos mais específicos do século $X X$, quando o cinema passa, não sem algumas escaramuças «escolásticas», a integrar o «sistema» das (belas) artes, ele próprio também uma invenção do século XVIII. ${ }^{1}$

1. E já que aqui falamos de cinema da «Europa de Leste», cumpre também observar que exactamente os mesmos problemas (de confundir os limites da realidade com os limites de um conceito) são levan- 


\section{Cinema: representação e realidade}

Se, nos dias áureos do esteticismo oitocentista (a ars gratia artis ou l'art pour l'art), Walter Pater pôde afirmar que toda a arte aspira à condição da música (no sentido da perfeita unidade de forma e conteúdo) (Pater, 1980: 106), na era da política e da arte de massas podemos dizer que toda a arte aspira à condição do cinema, como forma de arte política por excelência. Um bom exemplo disto é o mural político no realismo socialista. Embora se trate de pinturas em grande escala, há nelas uma certa qualidade que podemos designar como a aspiração cinemática da arte de propaganda, pela dimensão e sugestão narrativa. Da mesma forma, notamos em exemplos das diversas artes uma aspiração ao mesmo tipo de poder comunicativo de massas que o cinema possui natural e espontaneamente.

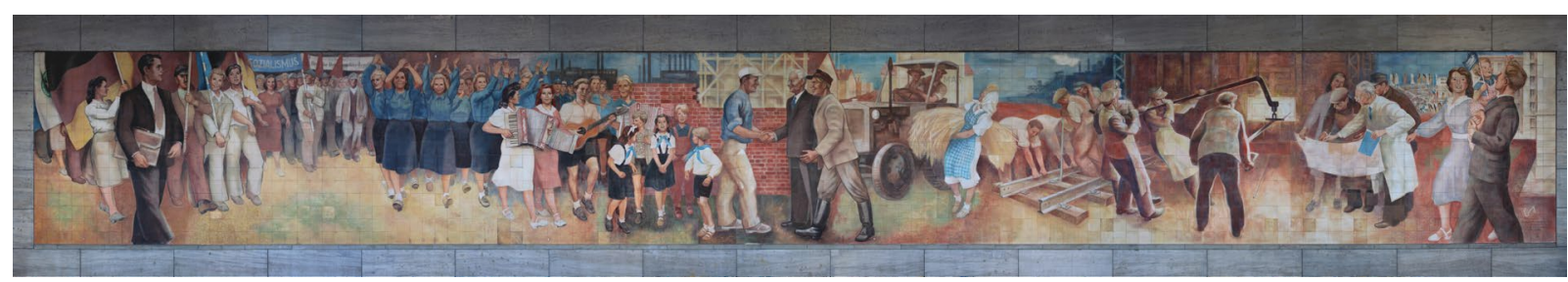

Max Lingner, Aufbau der Republik (1952/53), Haus der Ministerien, RDA, Berlim

O cinema não é apenas mais uma entre as artes já existentes. A invenção da câmara de filmar introduz novas formas de representar a realidade, transformando a nossa experiência da mesma, inclusivé o modo como passámos a ter experiência das outras artes, à semelhança de como a invenção da câmara fotográfica teve um tremendo impacto na pintura. Tudo isto recorda as ideias de Oscar Wilde em The Decay of Lying, quando propõe ser sobretudo a vida a imitar a arte, e não o inverso: «[...]As coisas são porque as vemos, e o que vemos, e como o vemos, depende das Artes que nos influenciaram. Olhar para uma coisa difere muito de vê-la. Não vemos seja o que for enquanto não vemos a sua beleza. Então, e só então, passa a existirn (Wilde, 1905: 41).2

Embora pareça à partida uma ideia algo bizarra ou meramente provocatória, trata-se de um fenómeno bastante comum em vários contextos da vida quotidiana: inicialmente, uma certa acção de alguém parece-nos generosa, até que modificamos esse nosso juízo porque certos aspectos da acção ganharam uma nova saliência para nós, ao mudar-se a perspectiva ou o modo de ver. Mas o modo como se representa a realidade pode fazer que as coisas sejam desse modo, pode determinar o que somos capazes de ver (um breve exemplo disto é que só vendo algo como mercadoria esse algo

tados por esta «ideia» (Europa de Leste), como bem aponta Peter Hames: «Parece que vivemos ainda com maneiras de pensar que dividiram de um modo impreciso a herança e cultura da Europa em Leste e Ocidente» (Hames, 2009: 2). ult seems that we are still living with ways of thought that have inaccurately divided European heritage and culture between East and Westı.

2. "Things are because we see them, and what we see, and how we see it, depends on the Arts that have influenced us. To look at a thing is very different from seeing a thing. One does not see anything until one sees its beauty. Then, and then only, does it come into existence» (tradução nossa). 
pode ser mercadoria). Basta pensar nas metáforas da linguagem comum que estruturam conceptualmente o nosso quotidiano, por exemplo, a metáfora do tempo como um recurso que pode ser gasto ou investido, por contraste com outras formas de entender o tempo, ou a metáfora da argumentação como uma batalha (que pode ser ganha), etc. Não é o mesmo ver a vida como uma viagem ou como um jogo. É assim, basicamente, como muitas representações artísticas funcionam: fazem-nos ver algo em termos de outra coisa, mudando o nosso modo de ver. Nas palavras de Lakoff e Johnson: "ua essência da metáfora é compreender e experienciar um tipo de coisa nos termos de outra» (Lackhoff e Johnson, 1980: 5, destaque nosso). ${ }^{3}$ Ao pensar nisto, a observação desconcertante e provocadora de Wilde, de como é aos impressionistas que Londres deve a qualidade peculiar dos seus nevoeiros (Wilde, 1905: 40) começa a soar muito mais plausível — o que vemos depende de como vemos. ${ }^{4}$

Aqui reside, parcialmente, a explicação da importância que as representações artísticas de um período histórico têm para a política. Controlar as representações é controlar o mundo, é desenhar as fronteiras da nossa experiência, as balizas conceptuais que circunscrevem aquilo que somos capazes de ver. Uma ideologia política é mais do que uma lista de afirmações sob a forma de um programa; é, antes de mais, um modo de ver a realidade, e, portanto, em consonância com o que foi dito antes acerca dos umodos de ver»), tem uma ineliminável dimensão estética (organização da experiência, reconfiguração da sensibilidade). A este propósito, vale a pena revisitar as observações de Susan Sontag no ensaio On Photography, acerca do papel da «ideologia» ao determinar a visibilidade de um evento e, portanto, a possibilidade de se ser «moralmente afectado» pelo mesmo (Sontag, 1977: 18-19). Basicamente, trata-se da ideia de que não há um momento "pré-valorativo» em que registamos certos "«factos» acerca do mundo, para então sermos moralmente afectados por eles. É só a partir de um esquema valorativo que certos eventos ganham «solidez ontológica»; ou seja, em muitos aspectos (não todos), o mundo é como é porque o representamos como assim sendo. É este um dos poderes fundamentais da arte: (re)organizar as nossas capacidades de representação. A arte ensina a ver, no sentido de que compreender uma obra de arte é um exercício imaginativo de ver o mundo através de um «esquema de valores», e não meramente de entender uma série de proposições acerca do mundo. ${ }^{5}$

Nas primeiras décadas do século XX, a mais debatida questão de estética filosófica acerca do cinema era a da sua justificação como arte (toda a early film theory é dominada por esta discussão), uma discussão que de certo modo continuava o mesmo debate suscitado antes pela introdução da fotografia.

3. «[...] the essence of metaphor is understanding and experiencing one kind of thing in terms of anothen (tradução nossa).

4. Se as metáforas que usamos na linguagem comum estruturam a nossa experiência do mundo e condicionam o que somos ou não capazes de ver, podemos então pensar nas representações artísticas como uma ampliação deste poder: têm a capacidade de mudar experiencialmente o modo como vemos o mundo e, portanto, como vivemos nele.

5. John Berger (1972) explicou esta ideia de forma magistralmente intuitiva, com a noção de que uma imagem artística não é apenas uma série de linhas e manchas de cor, mas também a corporização de um modo de ver (esquema de valores). 
Por contraste com as outras artes, a fotografia e o cinema começam por ser inovações tecnológicas, meios sofisticados de reprodução que vêm a incorporar pretensões estéticas, primeiro de uma forma subordinada ao teatro (ou à pintura, no caso da fotografia), e eventualmente procurando esclarecer a especificidade do seu próprio medium, mostrando como o cinema difere essencialmente do mero registo fílmico de uma representação teatral. São parte deste deste processo a introdução, por Erwin Panofsky, no ensaio de 1936, "Style and Medium in the Motion Pictures», dos conceitos de "dinamização do espaço» e "espacialização do tempo» (Panofsky, 1977: 354) (as duas características que marcariam a distinção fundamental entre o cinema e o teatro) ${ }^{6}$ e as ideias de Rudolf Arnheim (Arnheim, 1957) sobre o potencial artístico do cinema residir na exploração das limitações expressivas impostas pelo medium, relativamente ao que seria uma representação fílmica indiscernível da realidade nela representada. Os meios de reprodução industrial alteram a sensibilidade, o modo como se tem experiência do mundo, e, com o surgimento das massas na política, chega-nos também o fenómeno da arte de propaganda: arte dirigida às massas, com o fim de naturalizar, na sensibilidade destas, um certo modo de olhar a realidade. É neste contexto que emergem vários movimentos artísticos, como o futurismo italiano, a avantgarde russa do período revolucionário (que incluía também os seus futuristas) e o sucessor desta na construção e consolidação do estado soviético, o realismo socialista. Algo diferente irrompe na arte do século XX, como se os artistas começassem a levar muito a sério a 11 la Tese sobre Feverbach de Marx, que parafraseamos: os artistas têm apenas representado o mundo de diversas maneiras, a questão porém é transformá-lo. A figura do manifesto como parte da actividade artística (na verdade, como nova forma literária) é um resultado disto. ${ }^{7}$

Mas como pode a arte transformar o mundo? Eis uma resposta: transformando o modo como as pessoas o vêem. Ironicamente (se pensarmos no marxismo), nada é tão eficaz para transformar o mundo como o modo de o representar: temos de ser capazes de ver o modo como o mundo é precisamente como um modo de o mundo ser, e temos de ser capazes de ver o mundo de diversas maneiras a partir da compreensão de como ele é (e para tal, temos de o representar de algum modo); sem isso, não é possível

6. Na passagem em causa, Panofsky sintetiza ambas as características assim: «[...] all that which exists in space, even the walls of a room or the Rock of Gibraltar, can and should be invested with a semblance of movement [dinamização do espaço], while all that which happens in time, even the thoughts and feelings in the souls of men, can and should be made visible [espacialização do tempo]».

Por exemplo, um close-up não representa apenas o objecto focado pela câmara; representa também um acto psicológico de atenção. O flashback é a espacialização da memória, tornada visível. Os movimentos da câmara, os diferentes planos, os cortes, a montagem, as transições e as justaposições, conferem ao espaço cinemático um dinamismo impossível no espaço estático do teatro. No cinema, tudo se move e tudo é visível. E isto, por sua vez, abre um mundo de possibilidades representacionais.

7. É pouco depois do surgimento do Manifesto Comunista de Marx e Engels que os primeiros «manifestos» artísticos aparecem, ao longo da segunda metade do século XIX. No dealbar do século XX, os manifestos artísticos (inspirados politicamente tanto à direita como à esquerda) proliferam, chegando ao ponto de, em alguns casos (e.g. futurismo), a produção de manifestos anteceder a produção de arte que lhes corresponda, em vez de o manifesto vir «justifican» uma prática artística já em curso. Claro que o contraste muda de figura quando pensamos no próprio manifesto como mais uma forma artística, produzida pelas condições históricas. 
sequer começar a ver como ou porquê mudá-lo (independentemente de quais as razões para o fazer).

A importância do cinema nesta nova fase de desenvolvimento para a arte viria a tornar-se decisiva, como o próprio fluir deste ensaio pretende mostrar. Para o fazer, centramo-nos em dois exemplos de tratamento cinematográfico de temas medievais, em diferentes contextos sociais e políticos: a URSS em finais da década de 1930 e a Checoslováquia em finais da década de 1960.

\section{Dois cine-medievalistas: Sergei Eisenstein e František Vláčil}

No contexto dos sistemas políticos fascistas e comunistas do século XX, as pressões da censura e o controle exercido sobre as artes porvezes determinavam que só situando uma narrativa no passado era possível comentar o presente, o que não é exclusivo do cinema. Porém, as razões para o fazer são, neste caso, mais complexas. Por exemplo, observar os elos entre estado, guerra e estruturas políticas pré-existentes impõe naturalmente um interesse pela génese destas ligações no mundo pré-moderno, seja para as esclarecer, seja para as mistificar. O passado interessa também à propaganda como forma de produzir os mitos de que un regime político necessita, promovendo aquelas representações do mundo que servem um determinado programa político no presente. E a Idade Média, pelas razões já elencadas no começo deste artigo, serve, de formas variadas, tais propósitos. Se a Antiguidade Clássica era o farol da Europa das Luzes, para a Europa dos estados-nação emergentes, o período medieval será aquele onde tudo começa e a que tudo regressa. ${ }^{8}$

Os dois filmes em que nos focamos aqui, Alexander Nevsky (doravante, AN), de Sergei Eisenstein (1938), e Marketa Lazarová (doravante, ML), de František Vláčil (1967), oferecem-nos dois modos de representação cinematográfica daquilo a que chamaremos «ldade Média socialista», ou seja, duas imagens diferentes desta época, delimitadas pela relação particular de ambos os realizadores com o sistema socialista, em dois países e épocas distintas. ${ }^{9}$ Embora estes filmes tenham sido produzidos sob o mesmo tipo de regime político, foramno em contextos históricos, nacionais, culturais e políticos bastante diferentes. São precisamente alguns desses aspectos que procuramos, em seguida, esclarecer aqui, através da análise contextual dos dois filmes em questão.

8. A excepção óbvia será a relação entre o fascismo italiano e a antiga Roma. Isto é compreensível: que outro mito, para uma nação que nasce no século XIX, é mais poderoso do que a conexão histórica ao Império Romano?

9. Um estudo mais abrangente consistiria em averiguar se as representações da ldade Média nos países socialistas em geral exibem diferenças interessantes relativamente ao cinema histórico de países com regime fascista, por um lado, e ao cinema histórico no modelo de Hollywood, por exemplo, formando um todo diverso mas suficientemente unificado. Porém, isso requeriria bem mais do que um artigo. 


\section{1. Alexander Nevsky: «cinema histórico» para o Príncipe Moderno}

\section{Sinopse}

A acção de AN situa-se por volta do ano de 1241. O filme conta-nos a história da luta de Alexandre, príncipe de Novgorod, contra a Ordem Livónica e os seus aliados que, com o auxílio de um traidor, se apoderam da cidade de Pskov, a qual à época integrava a República de Novgorod, entidade política que existiu entre os séculos XII e XV. Apoiado pela «arraia-miúda» da cidade, e contado com alguma oposição de mercadores e boiardos, que temem as consequências de uma guerra, Nevsky enfrenta o exército inimigo na Batalha do Lago Peipus ou Chud (também conhecida como "Batalha no Gelo»). Como sub-trama, o filme inclui ainda uma história amorosa que se desenvolve em torno de uma disputa entre dois jovens guerreiros de Novgorod, Vasili e Gavrilo, pela bela Olga Danilova. Esta afirma que casará com aquele que provar ser mais valoroso em batalha. Protagonizando ambos actos de grande heroísmo, o «conflito» resolve-se quando Vassili, num gesto de cedência humilde e, simultaneamente, de afirmação, opta por casar com Vassilissa, a destemida filha de um Boiardo de Pskov que combate ao lado de ambos.

\section{Sovbiopic: da Montage ao Realismo Socialista}

AN foi realizado em 1938, em plena consolidação do stalinismo na URSS, durante o período das Grandes Purgas e imediatamente antes de eclodir a Segunda Guerra Mundial, tendo granjeado ao realizador, Sergei Eisenstein, não apenas a reabilitação aos olhos das autoridades e do próprio Stáline, que aclamou o filme, como também um Prémio Lénine.

Neste período, é indubitável a importância do cinema para o regime soviético nascido da revolução de Outubro de 1917. É o próprio Lénine quem, de acordo com Anatoly Lunacharsky, ${ }^{10}$ afirma: "de todas as artes, o cinema é para nós a mais importanteı) (citado por Thompson e Bordwell, 2019: 107). E de facto, na sua primeira década de existência, a União Soviética vem a revelar-se, por vários motivos, um incrivelmente bem-sucedido laboratório de experimentação artística em geral e cinematográfica em particular. Nesse campo, destacam-se Dziga Vertov e Lev Kuleshov, mas o mais reconhecido realizador soviético deste período formativo é, sem dúvida, Sergei Eisenstein. No entanto, apesar de todo este fervilhar de experimentalismo e vanguardismo (cuja relação com o passado sempre se caracteriza pela ruptura e o «começar de novo»), a filmografia eisensteiniana tem uma forte componente histórica, ${ }^{11}$ ainda que, numa fase inicial, ela se reporte a eventos então bastante recentes, como é o caso de Greve (Стачка, 1925), Couraçado Potemkine (Броненосец

10. Primeiro ministro da educação da URSS, escritor, ensaísta e crítico. Foi produtor de uma peça da artista avant-garde Lyubov Popova e escreveu acerca de Mayakovsky, entre outros.

11. Não deixa de ser curioso que a procura por uma forma inovadora de fazer cinema, tal que enquanto arte própria tenha tido expressão em filmes de carácter histórico, ainda que estes representem eventos recentes. Com o novo regime triunfante vem a necessidade de uma nova forma de contar a história. Curioso é também, neste contexto, o processo de urecuperação» de figuras distintas no passado da Rússia, como sucedeu com Ivan, o Terrível. 


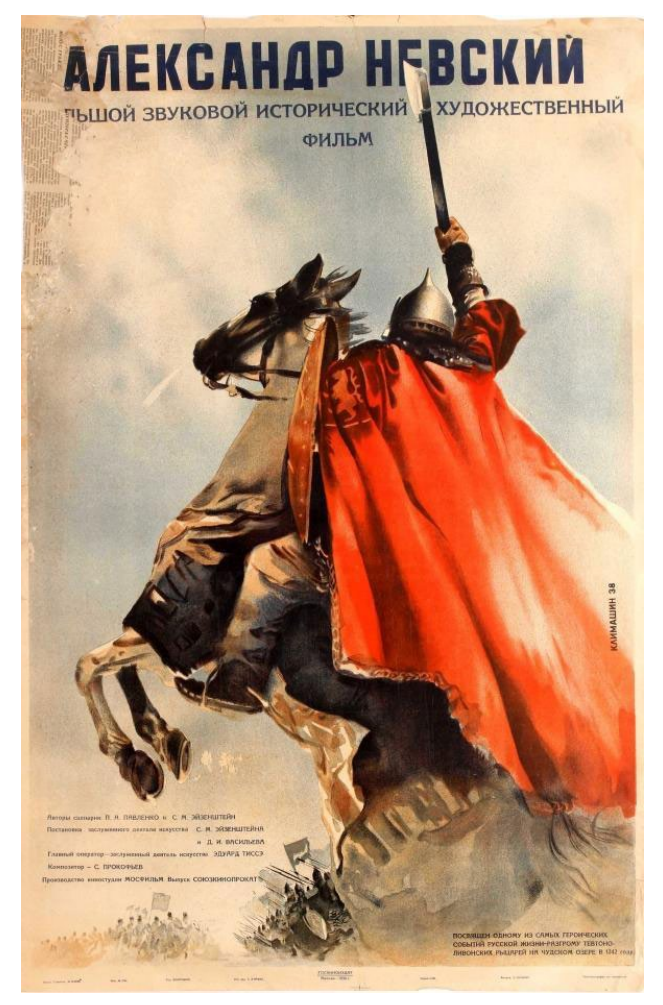

Alexander Nevsky, Sergei Eisenstein

Потёмкин, 1925) e Outubro (Октябрь «Десять дней, которые потрясли мир», 1928). ${ }^{12}$ É de referir que o projecto a que Eisenstein se dedica depois de AN, ligado à construção do Canal de Fergana no Usbequistão, e que vem a ser interrompido por decisão das autoridades, o impele uma vez mais a aventurar-se na temática «histórica». O que a início fora concebido como uma celebração das transformações levadas a cabo pelo socialismo nas repúblicas do Sul rapidamente se converte num projecto em três partes, nunca levado a termo, que abrangeria um período histórico entre a época de Tamerlão e o presente, tendo por elemento comum a água como força natural e o esforço humano por dominá-la, servindo também objectivos políticos (O'Mahony, 2008: 171-173). O projecto cinematográfico a que Eisenstein se entregou em seguida foi Ivan, о Terrível (Иван Грозный), о seu grande trabalho «histórico», filmado ainda em plena guerra, também com Nikolai Cherkassov, o actor que encarna o príncipe de Novgorod em AN. Assim, a representação de eventos históricos é uma constante no trabalho de Eisenstein, sendo que as principais diferenças, na produção artística do realizador, entre a «fase» marcada por projectos como AN e Ivan, o Terrível, e a ufase» que a antecede, residem na maior ou menor proximidade temporal desses eventos, por um lado, mas também no facto de os filmes da produção anterior tratarem eventos e não tanto as vidas de figuras históricas. Porém, como sugere a própria estrutura do projecto abortado no Usbequistão, Eisenstein via uma continuidade fundamental em todos estes trabalhos.

Quando comparado com Greve ou Couraçado Potemkine, AN é um dos filmes formalmente menos ousados de Eisenstein. Por exemplo, ao contrário do que sucede em Couraçado, onde se manifesta uma preocupação de carácter trágico com a unidade da acção, assente sobretudo na composição/montagem (Eisenstein, 2004: 6), em AN o fio condutor decorre do argumento. O experimentalismo formal e cinematográfico que caracteriza os seus primeiros trabalhos é secundarizado, passando a narrativa - algo esquemática - a assumir um lugar de maior preponderância. $O$ estilo cinematográfico torna-se mais convencional, com a notória excepção das sequências da batalha no gelo e celebração da vitória, sobretudo em termos da combinação entre imagem e música. Este câmbio é em parte determinado pelas circunstâncias históricas em que AN é realizado, as quais já referimos, e

12. Isto levanta questões complexas acerca da natureza e limites da categoria «filme histórico»: quão temporalmente remotos têm de ser os eventos representados num filme para que se possa dizer, bona fide, que se trata de um «filme histórico»? 
pela participação de Dimitri Vassiliev na realização e de Piotr Pavlenko no argumento, dois homens integralmente comprometidos com o regime e que teriam integrado a equipa de Eisenstein de forma a garantir que o realizador se mantinha disciplinadamente dentro dos cânones do realismo socialista, sobretudo depois da desastrosa experiência com $\bigcirc$ Prado de Bezhin, de 1932, realizado num tempo em que os criadores do Montage são já acossados pelas autoridades soviéticas e os seus princípios estéticos rejeitados (Eisenstein, 2004: 10-15; Thompson e Bordwell, 2019: 123). Porém, a ser verdade, o carácter mais tradicional do filme também se pode explicar pelo recurso, por parte do argumentista, a fontes medievais, que fornecem, pelo menos em traços muito gerais, a trama central do filme (Ostrovski, 2006: 309). É difícil apurar com total exactidão as fontes usadas, sobretudo porque temos de recorrer a textos traduzidos ou a informação em segunda mão, pelo que as hipóteses que aqui apresentamos são apenas isso mesmo: conjecturais. Ainda assim, cremos ser possível dizer algo potencialmente esclarecedor sobre esta questão.

Um dos aspectos mais estudados em AN prende-se com a reconstituição da Batalha no Gelo, que está descrita em várias crónicas, anais e hagiografias medievais e modernas, de formas muito distintas. Na Vida de Alexandre, um relato hagiográfico datado de meados do século XIII, o autor procura criar um efeito dramático ao descrever este conflito estabelecendo a seguinte comparação: «[...]Havia... um barulho do quebrar das lanças e o som de espadas embatendo umas nas outras como se o lago gelado se movesse[...]» (Ostrowski, 2006: 299). ${ }^{13}$

Segundo Donald Ostrowski (2006: 299), esta imagem servia para mostrar que o gelo rangia durante a batalha. Ora se atentarmos nos efeitos sonoros que, no filme, acompanham o desenrolar da batalha, escutamos de forma contínua, com especial saliência e insistência, o embater de lanças e espadas. Tal saliência e o impressionante efeito rítmico que confere às imagens, indicia uma tentativa de dar corpo a esta ideia da intensidade do som transmitida pela Vida de Alexandre, intenção essa declarada, aliás, pelo próprio Prokofiev o autor da banda sonora (Bartig, 2017: 71).

Outro indício que aponta para o uso directo de fontes medievais diz respeito ao destino de muitos soldados da Ordem, que acabam por se afogar no lago, quando o gelo começa a ceder e se quebra. $O$ artigo que temos vindo a citar (Ostrowski, 2006) traça a arqueologia deste motivo narrativo, concluindo que é ao próprio Eisenstein que se deve a associação desta notícia à batalha. Ainda segundo este autor, Eisenstein terá ido buscar inspiração a outro confronto militar, também referido em várias obras da literatura histórica medieval russa: o confronto entre Yaroslav, antepassado de Alexandre Nevsky, e Sviatopolk, Grão-príncipe de Kiev, ocorrido em 1016. Esta batalha é referida tanto na Vida de Alexandre como nas várias versões Da Primeira Crónica ou Crónica de Nestor ( em russo, Повесть временных ле, que, traduzindo à letra, significa «Estórias de tempos passados», textos que, juntamente com as Vitae de Boris

13. «There was ... a noise from the breaking of lances and a sound from the clanging of swords as though the frozen lake moved» (tradução nossa). 
e Gleb, registam a ocorrência de uma batalha num lago gelado (Ostrowski, 2006: 305-307).

A estes textos elencados por Donald Ostrowski podemos acrescentar um terceiro, a Terceira crónica de Pskov, onde também aparece o motivo da quebra do gelo e do afogamento subsequente de soldados inimigos. Porém, aqui a notícia surge associada a uma terceira batalha, a que teve lugar em 1234 perto do rio Emajõgi, que flui no território da actual Estónia e desagua no Lago Peipus, batalha que opôs o pai de Alexandre Nevsky, Yaroslav, à Irmandade da Espada da Livónia (Savignac, 2016: 45). Esta crónica poderá ter servido como fonte para a redação do argumento, já que relata outros eventos relacionados com o saque de Pskov pelos cavaleiros da Ordem, também reportados por esta crónica e igualmente retratados no filme:

\begin{abstract}
[...] Os homens de Pskov marcharam e lutaram contra eles, mas os alemães saíram vitoriosos e levaram alguns deles prisioneiros. Depois marcharam para Pskov e puseram o posad em chamas. Permaneceram na cidade por uma semana e depois retiraram-se, levando consigo como reféns os filhos dos habitantes mais importantes. Alguns cidadãos de Pskov tinham encetado uma correspondência traiçoeira com os alemães: o traidor Tverdilo Ivankovich era um deles, e ele começou a governar Pskov com os alemães, submetendo aldeias que pertenciam a Novgorod. Outros habitantes de Pskov levaram as suas mulheres e filhos para Novgorod [...] (Savignac, $2016: 47) .{ }^{14}$
\end{abstract}

É sobretudo de notar que o nome do traidor, Tverdilo Ivankovich, que encontramos no filme de Eisenstein também figura neste texto.

Tendo em conta semelhantes indícios, podemos dizer que, se em termos cinematográficos AN exibe uma maior conformidade com o realismo socialista e, na verdade, converge também em maior grau com o cinema histórico mais convencional, no que toca à recolha de informação sobre a época passada e na recriação de ambientes medievais, Eisenstein procurou documentar-se bem sobre a Idade Média, lendo fontes primárias e escutando a opinião de especialistas (Iurenev, 1988: 143-145, em Ostrowski, 2006: 309).

A pesquisa de informação em fontes medievais para a realização do filme é visível também na recriação cénica do ambiente histórico particular em que se desenvolve a accão do filme, seja nos cenários e nos adereços ou na música (Bartig, 2017: 93-95). Um dos pormenores que mais chama atenção no que toca ao uso directo de reportório medieval é o desenho dos capacetes do Grande Mestre da Ordem e dos seus subordinados mais directos. Alguns autores têm salientado o seu aspecto desumanizante (Thompson e Bordwell, 2019:

14. «The men of Pskov marched out and fought against them, but the Germans were victorious and took some of them prisoner. Then they marched to Pskov and put the posad to the torch. They stood at the town for a week and then they withdrew, taking the children of leading citizens as hostages. Some citizens of Pskov had been in treasonous correspondence with the Germans: the traitor Tverdilo Ivankovich was one of them, and he began to rule Pskov with the Germans, subduing villages which belonged to Novgorod. Other citizens of Pskov took their wives and children to Novgorod» (tradução nossa do inglês). 
237), contudo, esta escolha não é apenas condicionada por uma vontade de vilipendiar e denegrir o mais possível o inimigo, representando de forma vívida a sua desumanidade por ocultarem o rosto. Na verdade, estes capacetes são um exemplo claro de como em AN se estabelece uma ponte genuína entre o passado medieval e a época em que o filme foi rodado. Para tal, Eisenstein parece muito claramente ter recorrido ao famoso Codex Manesse, datado do início do século XIV,,$^{15}$ ou, pelo menos, a alguma reprodução do seu conteúdo pictórico (Haydock, 2009: 34). Trata-se de um cancioneiro ricamente iluminado e que recolhe a poesia dos Minnesänger. O mesmo códice serviu de inspiração para os capacetes dos principais cavaleiros, de forma a distinguir os lideres dos restantes soldados e cujo simbolismo parece ser deliberado, a ajuizar pelo destino dos seus possuidores (Haydock, 2009: 32-34).16
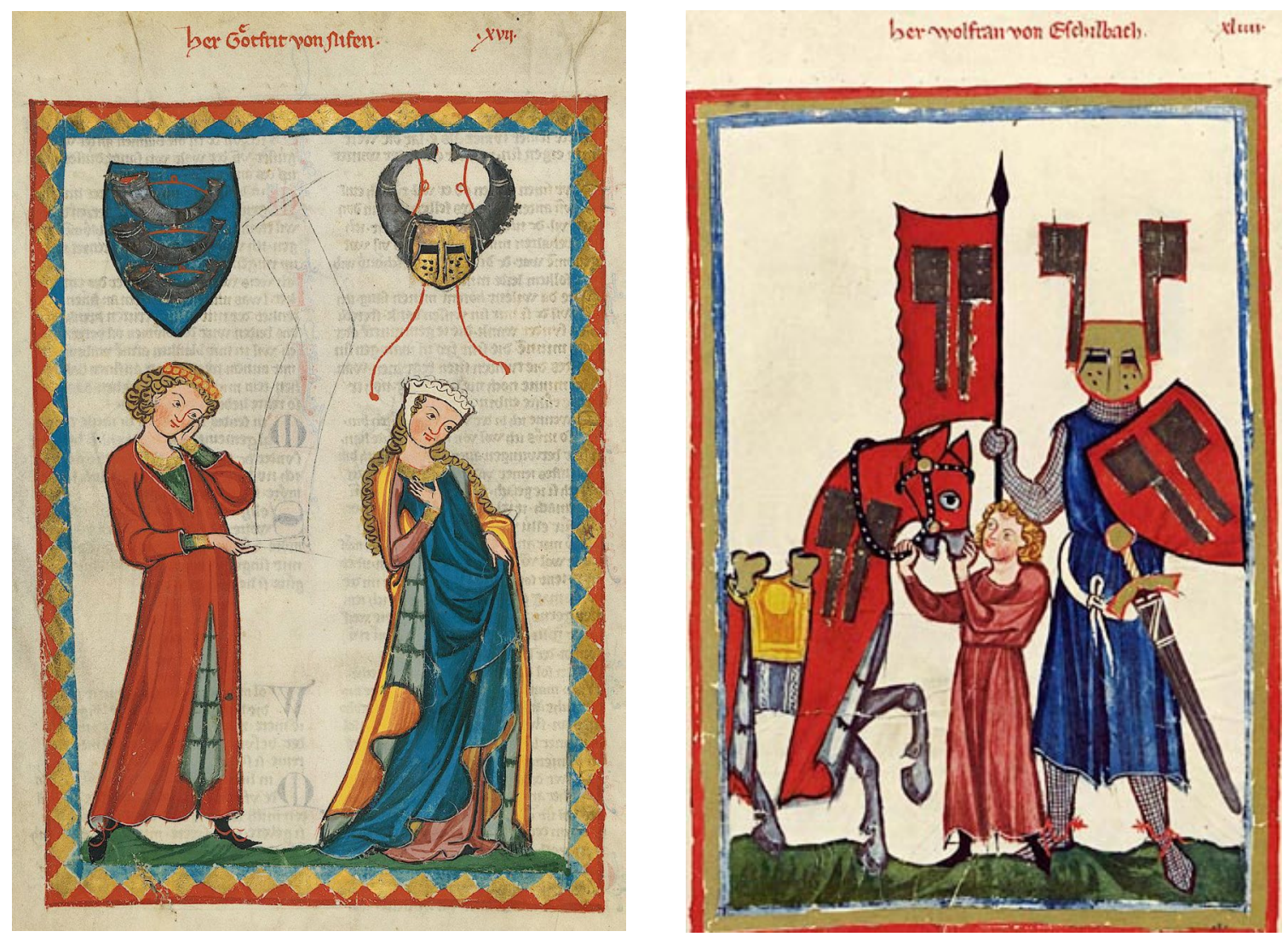

Gottfried von Neifen e Wolfram von Eisenbach UB Heidelberg, Cod. Pal. germ. 848, ff. 32v e 149v

15. Heidelberg, UB Heidelberg, Cod. Pal. germ. 848. Hoje totalmente digitalizado e disponível para consulta: https://doi.org/10.11588/diglit.2222\#0001.

16. Será mera coincidência que Eisenstein tenha escolhido representar os capacetes de algumas das mais famosas figuras da literatura medieval alemã, como Wolfram von Eisenbach ou Gottfried von Neifen? O outro capacete copiado deste códice é o da garra, que pertence ao conde Otto von Bottenlaube (f. 27r), ligado à ordem teutónica. Mais curioso ainda: o capacete com a mão não está representado no Manesse, o que sugere que a intuição de Haydock (2009: 62) sobre a relação deste símbolo heráldico com o nacional-socialismo está correcta. 


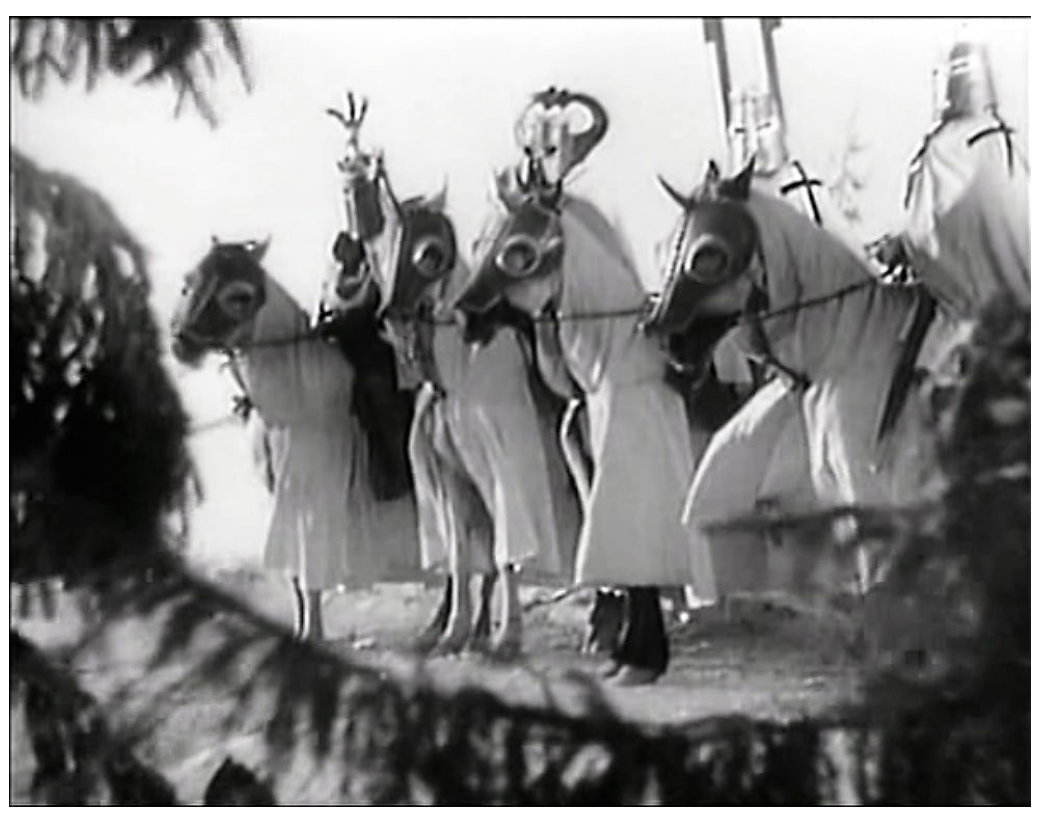

Alexander Nevsky, Sergei Eisenstein

Por outro lado, Eisenstein mostra também uma preocupação em representar com acuidade o traje dos cavaleiros teutónicos, para o que terá, muito provavelmente, recorrido ao mesmo códice, já que no fólio $264 \mathrm{v}$ se encontra uma representação do cavaleiro Tannhäuser envergando as vestes da ordem:
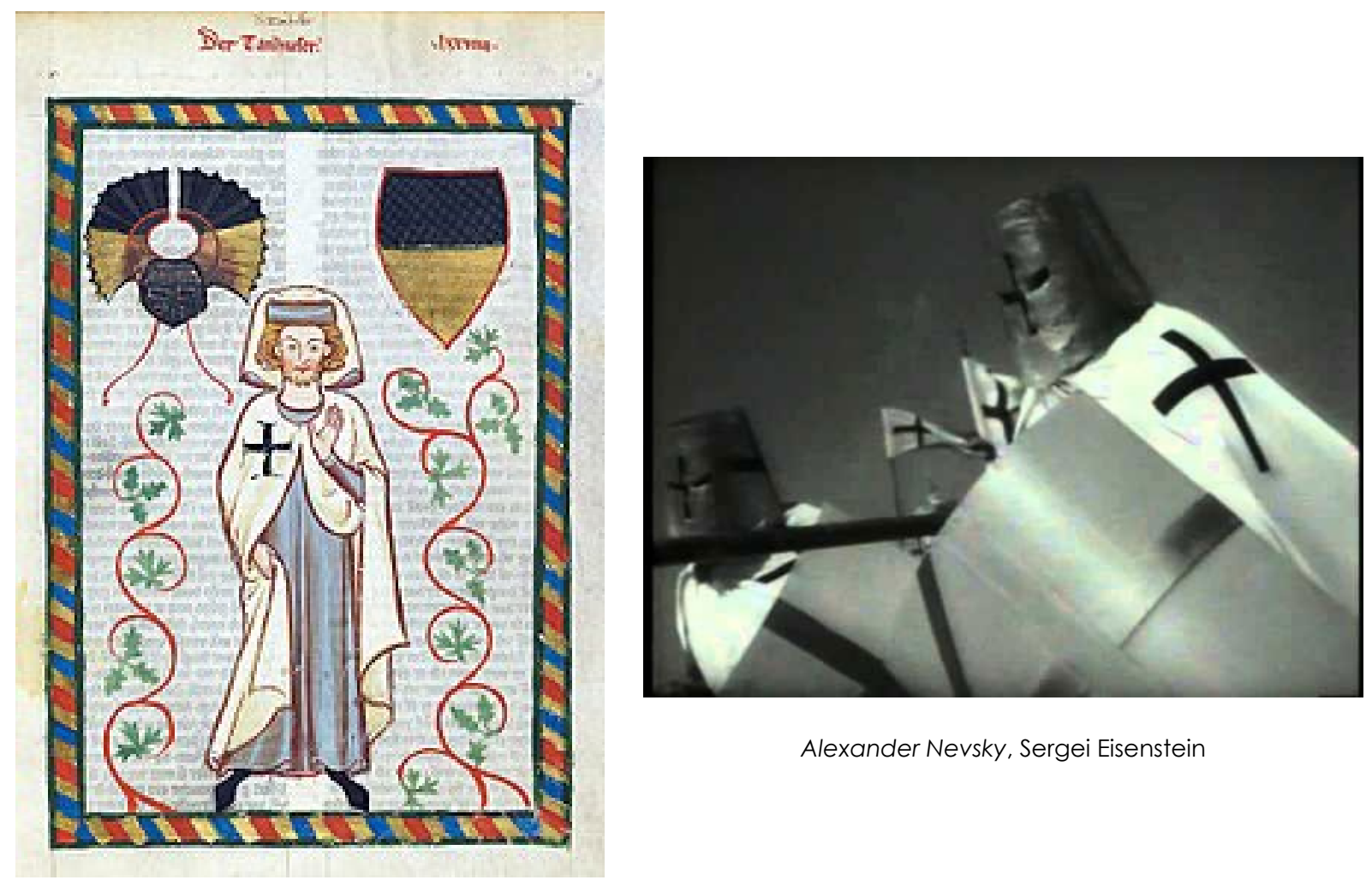

Alexander Nevsky, Sergei Eisenstein

UB Heidelberg, Cod. Pal. germ. 848, fo. 264v 
O recurso à iconografia deste códice germânico sugere que a relação de Eisenstein com o passado medieval é mais complexa do que pode à primeira vista parecer ${ }^{17}$ e que a tentativa de recriar o ambiente daquela época não se limitou à adaptação de obras literárias ou documentais contemporâneas do cineasta, levando-nos a considerar com alguma cautela a ideia de que a escassez de fontes poderá ter sido uma motivação (ou a principal motivação) na escolha de Nevsky como protagonista da história, por essa escassez permitir uma maior liberdade artística e maleabilidade no tratamento dos temas. ${ }^{18} \mathrm{Mas}$ tampouco podemos deixar de observar que o conhecimento e a utilização da iconografia medieval manuscrita como inspiração é aqui combinado com o recurso a adereços cuja aparência se poderá basear em equipamento mais moderno. Tome-se como exemplo disto os capacetes de alguns soldados (não pertencentes à Ordem) que combatem no exército teutónico. Estes podem ser vistos como reminiscentes do Stahlhelm, equipamento completamente moderno que foi introduzido no exército alemão em 1916, durante a Primeira Guerra Mundial, mas modernizado nas décadas seguintes. Se assim for, este será mais um indício a favor de ver AN como uma obra de propaganda stalinista (que também seguramente é), pretendendo exaltar o sentimento nacional russo ao mesmo tempo que apela ao estado de alerta permanente em relação à Alemanha nacional-socialista, ameaça essa que se fazia sentir nos anos anteriores à assinatura do pacto de não agressão germano-soviético, em 1939. Contudo, não pode ser completamente descartada a possibilidade de Eisenstein estar a olhar, uma vez mais, para épocas mais recuadas, já que este capacete também partilha algumas semelhanças com a celada (em inglês, «sallet»), ou um dos antepassados da mesma. Trata-se de um tipo de capacete que se começa a usar em toda a Europa a partir do século XV, mas que que se torna muito popular sobretudo em território alemão (Oakeshott, 1999: 291). ${ }^{19}$ Talvez a introdução da viseira, que lembra o bico de uma ave (uma alusão à águia alemãe), seja uma adição do realizador, de forma a tornar mais explícita a atitude predatória do exército alemão, independentemente de considerações históricas. Seja como for, evoca um claro contraste com o soldado russo, que combate de cara destapada.

17. A importância do Codex Manesse na construção imagética de AN não se esgota nos exemplos dados, ele poderá também ter inspirado a representação dos monges católicos (48v, 75v), os planos dos quatro cavaleiros principais no ecrã (43v), mas estas ligações parecem menos evidentes.

18. Esta explicação para a escolha de Alexander Nevsky por Eisenstein foi-nos trazida à atenção, em comunicação pessoal, por Haneen Hannouch, especialista em Eisenstein, a quem agradecemos.

19. Para um exemplo de celada alemã veja-se https://www.metmuseum.org/art/collection/search/26453. 


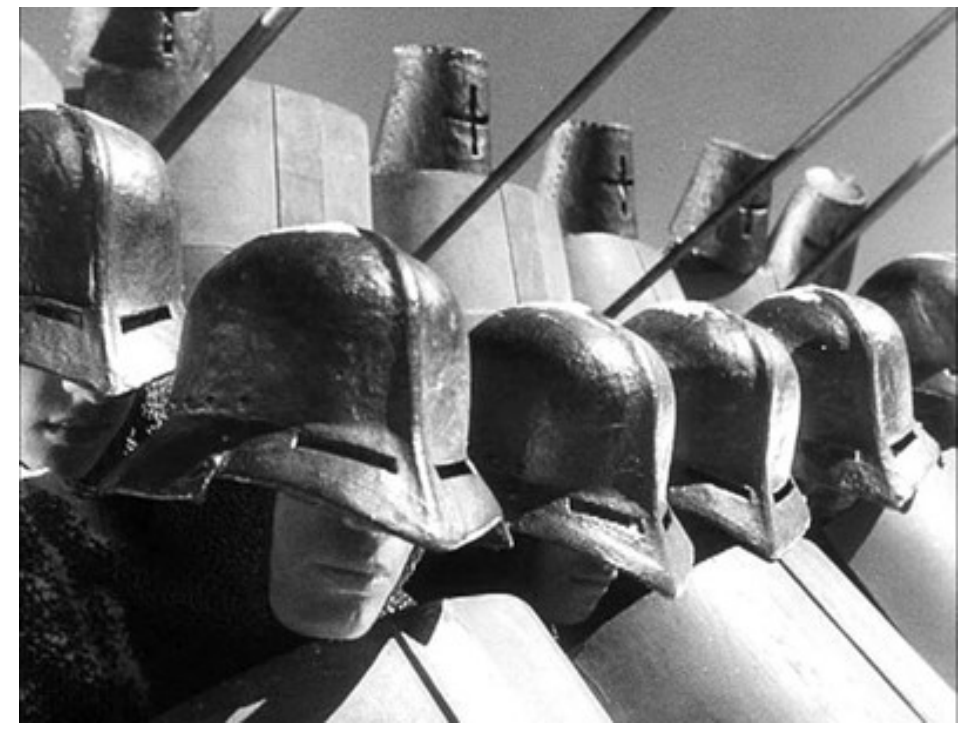

Alexander Nevsky, Sergei Eisenstein

Pelos exemplos dados, vemos que Eisenstein (ou a sua equipa) não se coibiu de procurar inspiração nos testemunhos mais antigos da cultura germânica, de forma a construir uma oposição entre os russos e os alemães. Contudo, podemos talvez falar também de antagonismo não só no que diz respeito à representação de figuras ou no que elas representam, mas também no que diz respeito à natureza do cinema e do que este representa. Na verdade, Eisenstein parece ter criado AN tendo por referência um dos mais importantes filmes históricos alemães, Os Nibelungos (Die Niebelungen), de Fritz Lang (1924), reagindo à obra do cineasta alemão ou através da paródia ou da diferenciação estilística (Haydock, 2009: 33-34). Ao mesmo tempo que demonstra ter algum conhecimento da cultura manuscrita da Alemanha medieval, Eisenstein mostra também um conhecimento apurado da estética e da cinematografia recentes ligadas àquele país, permitindo-se "comentan" o mesmo, de um modo puramente pictórico ou visual, sem "pistas literárias» - algo que não se coaduna com a prescrição de transparência semântica no realismo socialista. Neste sentido, apesar da abordagem mais tradicional, podemos dizer que AN contém uma série de pequenas subversões ou desvios relativamente ao umolde» a que, à primeira vista, parece inteiramente submisso. Na verdade, alguns dos aspectos que dão a AN o seu tom de obra exemplar do realismo socialista poderão ser na verdade consequência de uma mais básica fidelidade ao espírito medieval da representação.

\section{2. Marketa Lazarová: a subversão do ıfilme histórico»}

\section{Sinopse}

O enredo de ML desenrola-se durante o reinado de Venceslau I, embora isso nunca seja explicitamente afirmado no filme. Kozlik (o Bode) é o líder de um clã que controla um território inóspito, Roháček, na região de Mladá Boleslav (Boémia Central). Para sobreviver aos rigores do inverno (e talvez mesmo para 
manter uma certa forma de existência), o clã recorre ao banditismo. Quando Mikoláš e Adam, filhos de Kozlik, atacam uma caravana de nobres alemães que viaja sob protecção do rei, tomando como refém entre eles o jovem Christian, futuro bispo de Hennau (pelo qual se virá a apaixonar uma das irmãs de ambos, Alexandra), o rei envia uma força expedicionária, liderada por um capitão conhecido pela alcunha de «Pivo» («Cerveja»), com o fito de derrotar e capturar o clã Kozlik e impor a sua lei no território. Entretanto, Mikoláš dirigese ao chefe do clã vizinho, Lazar, senhor de Obořiště (que também pratica o banditismo), pedindo-lhe ajuda na defesa contra essa ameaça comum, mas este recusa-se, invocando a sua neutralidade e a autoridade do rei. Numa altercação exacerbada pelos subalternos de Lazar, Mikoláš é brutalmente agredido e quase morto. Mais tarde, já recuperado, regressa para se vingar de Lazar, matando-lhe o filho, raptando-lhe e violando a filha, Marketa, que fora prometida ao convento. Num revés inesperado, esta acaba por se apaixonar pelo seu captor e violador. Por seu lado, Mikolas, também retribui o sentimento, acabando por desrespeitar as ordens Kozlik, que pretende torturá-la. Entretanto, já na segunda parte do filme, Adam é capturado por Pivo e obrigado a guiar o exército do rei até ao refúgio do seu clã, na floresta. Adam é morto ao tentar fugir, desencadeando assim de um modo impulsivo e desordenado a batalha, que termina com a derrota dos Kozlik. Entretanto, numa sequência pouco clara, cujo sentido se vai mostrando entre flashbacks e cortes, Christian hesita, foge, procura Alexandra, e regressa a Roháček. 0 patriarca dos Kozlik, o infame Bode, é levado a ferros para os calabouços do rei. Por insistência de Mikoláš, alguns irmãos sobreviventes juntam-se-lhe na tentativa de o libertar, atacando a prisão em Boleslav. Antes de partir nessa missão, Mikoláš pede a Marketa que regresse a Obořiště e peça permissão ao pai para casarem. Ao mesmo tempo, Alexandra encontra novamente Christian e acaba por matá-lo. Embora relutante, Marketa regressa a casa do pai mas este expulsa-a, acusando-a de se ter mantido na relação ilícita com Mikoláš por sua vontade, quebrando o useu» voto com Deus. Marketa segue então para o convento, que acaba também por abandonar, partindo em busca de Mikoláš, entretanto ferido mortalmente no ataque à prisão de Boleslav. Numa sequência que parece claramente alegórica, Pivo casa Marketa com Mikoláš, pouco antes de este ser conduzido em braços, já com a vida por um fio, ao cadafalso, juntamente com o pai. O filme termina mostrando Marketa, grávida, caminhando sozinha e ignorando os apelos do clérigo errante para que o acompanhasse. Segundo o narrador, Marketa virá a criar o filho que gerou com Mikoláš, de nome Vaclav, bem como do filho nascido da relação entre Alexandra e Christian, o qual é plausível identificar com a criança pela mão de quem Marketa sai do convento, embora seja igualmente possível tratar-se de uma prefiguração simbólica do seu próprio filho.

\section{Transição entre mundos: lobos e cordeiros}

O filme foi realizado em 1967 por František Vláčil, um dos mais prolíficos realizadores da Nova Vaga (Nová VIna) checoslovaca. Este movimento artístico e estético foi preconizado por um grupo de realizadores quase 
inteiramente oriundo da escola de cinema Estatal (FAMU) e esteve intimamente relacionado com as mudanças políticas e sociais ocorridas na Checoslováquia ao longo da década de 1960, as quais culminaram em 1968 nas reformas políticas instauradas pelo governo de Alexander Dubček e que ficaram conhecidas como "Primavera de Praga» (Hames, 2009:8; 2018: 81). O cinema criado neste período pelos representantes da Nova Vaga contrasta com o cinema produzido em décadas anteriores, e, portanto, também com o tipo de utilização artística do passado - e.g. os filmes realizados em conformidade com o papel atribuído a figuras históricas como Jan Huss como a trilogia de Otakar Vávra, o realizador mais evidentemente ligado ao "filme histórico» (Hames, 2009: 15-19), nos anos 1950 - um uso que espelhava o tratamento de figuras históricas russas pelo cinema soviético durante o stalinismo. Curiosamente, a representação cinematográfica de figuras como o fora-da-lei Juraj Jánošík (uma espécie de Robin Hood eslovaco seiscentista) parece ter sido mais popular nas décadas de 1920 e 1930 e na década

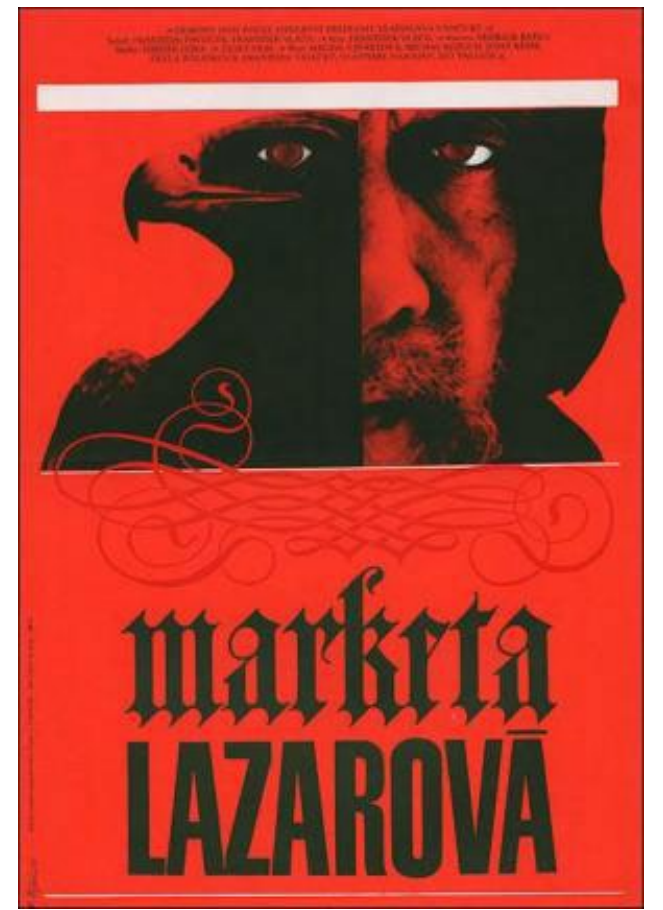

Marketa Lazarová seguinte à da «Primavera de Praga» (Hames, 2009: 19-22), o que pode indicar ou um maior desconforto, por parte da doutrina estética oficial, com a figura do fora-da-lei, ou pode apenas reflectir parcialmente o facto de Jánošík estar ligado ao folclore eslovaco e polaco.

O cinema checoslovaco da década de 1950, no qual se distingue precisamente um realizador como Vávra, era mais claramente orientado pelos preceitos estéticos e ideológicos definidos pelo realismo socialista (Hames, 2009: n.6), que prescrevia uma arte engajada e moralmente edificante, veiculadora dos valores político-sociais defendidos pelas camadas dirigentes dos países comunistas. Regra geral, e este é um aspecto que obviamente transcendia a realidade checoslovaca, tais filmes encenavam uma realidade mitificada, esquemática, na qual invariavelmente um herói, munido de todas as virtudes cardinais comunistas (abnegação, rigor, sacrifício, coragem, rectidão moral) acabava por triunfar sobre os que pretendiam destruir ou que ameaçavam esse modo de vida. Ora, o grupo da Nova Vaga checoslovaca pautava-se por uma recusa de narrativas ou de argumentos deste género, rejeitando a idealização da sociedade, ou a visão salvífica, heróica e edificante da história e da revolução comunista, relegando, ao invés, os grandes eventos históricos para o pano de fundo da vida do homem comum (Closely Watched Trains, Jǐrí Menzel, 1966), dando também espaço à emergência de heróis muito pouco heróicos, quando julgados à luz do paradigma socialista (Hames, 2014). O quotidiano e os pequenos detalhes do dia-a-dia de indivíduos na sociedade 
checoslovaca socialista (Report on the Party and the Guests, Jan Jan Nermec, 1966), temas como o amor e a amizade entre jovens (Loves of a Blond, de Miloš Forman, 1965 ou Daisies, de Vera Chytilová, 1966), o absurdo e o humor negro (The Cremator, Juraj Herz, 1969), ou ainda a temática de filmes «fantásticos», com elementos surrealistas (Valerie and Her Week of Wonders, de Jaromil Jireš, 1970). Em suma, é a pequena estoria, que não será por isso menos política, tomando o lugar da grande narrativa (Liehm, 1974: 13-14). Neste sentido, pode afirmar-se que a Nova Vaga checoslovaca representa, de certo modo, um retorno, embora num novo registo, ao "laboratório experimentalista» da avant-garde, pelo qual passara o cinema soviético dos anos de 1920, antes da «normalização» stalinista e o triunfo do realismo socialista, no seu projecto de «reestruturar artisticamente» a sociedade (Groys, 1992: 21).

Em termos cinematográficos, alguns dos pressupostos estéticos deste movimento exibem correspondências inequívocas com trabalhos de realizadores que integravam a Nouvelle Vague francesa, como Robert Bresson ou Alain Resnais, ou que retomavam tradições cinematográficas do período anterior à guerra, mediadas pela revisitação de filmes desse tempo ou pelo contacto, na FAMU, com professores cuja estreia na realização profissional de cinema tivera lugar nesse período (Hames, 2018: 78-79). O recurso a actores não profissionais, o uso de movimento de câmara ou dollying - que, curiosamente, era visto pelas autoridades como uma técnica «burguesa», ${ }^{20}$ a interposição de diálogos longos, a recusa de linearidade narrativa, a influência do teatro, além da presença de um humor mordaz e absurdo foram elementos recorrentes no cinema feito neste período (Hames, 2009: 2014).

Contudo, e embora rejeitem a representação épica, grandiosa e «moralmente didáctica» da história, alguns realizadores ligados a esta Nova Vaga enveredaram pelo cinema histórico, como é o caso de Vávra (embora este pertença a uma geração anterior, e mais alinhado com o realismo socialista). Entre estes, destaca-se precisamente František Vláčil, que, além de $\mathrm{ML}$, é responsável por outros dois filmes diegeticamente situados em épocas passadas: A Armadilha do Diabo (D́áblova past) de 1962, que revisita o século XVII, enquanto Vale das Abelhas (Údolívčel), de 1968, gravado no ano anterior, o mesmo em que ML vem a público, retoma a atmosfera medieval do século XIII, que permeia também ML. Na verdade, o guarda-roupa de Vale das Abelhas foi inteiramente reutilizado a partir de $\mathrm{ML}$, por razões que se prendiam com os custos de produção.

ML partilha com a obra de realizadores da Nova Vaga já aqui referidos aspectos de concepção, como seja, por exemplo, o uso de actores não profissionais enquanto forma de garantiruma autenticidade e uma naturalidade suplementares, algo que fora já tentado no cinema soviético inicial, embora por razões distintas (Thompson e Bordwell, 2019: 120-122). Porém, Vláčil foi mais

20. Pelo menos um professor na FAMU, Jaroslav Kučera, tinha, ao que parece, esta nota na sua usebenta», porque, segundo as prescrições, o realismo socialista deve clara e didaticamente mostrar os aspectos positivos e negativos (o que imitar e o que evitar) numa dada situação, ao passo que o dollying tende a mostrar tudo como «igualı, confundido, misturado num mesmo plano. Referido por Jan Němec em entrevista: https://youtu.be/Wz-JUV8ssZY. 
longe. Ambicionando mostrar a Idade Média utal como ela era», ${ }^{21}$ investigou o modo de vida de sociedades pré-modernas (uíndios do Brasil e aborígenes australianos») (Hames, 1985: 39), como forma de tornar os cenários, adereços e ambientes tão realistas quanto possível. Consequentemente, submeteu toda a equipa a uma experiência de imersão no que considerava serem as condições de vida do século XIII: toda a equipa viveu durante algum tempo nos bosques, construindo cenários com instrumentos rudimentares, caçando e vivendo com escassos recursos (Gunning, 2013). Não será, portanto, excessivamente aventuroso afirmar que o interesse peculiar de Vláčil na reconstrução fílmica do mundo medieval tem um pendor mais antropológico do que literário, por contraste com o tipo de veracidade almejada por Eisenstein ao construir o mundo de Alexander Nevsky.

O argumento do filme resultou sobretudo da adaptação, difícil, longa e penosa, do romance homónimo escrito em 1931 por um acarinhado escritor checoslovaco, Vladislav Vančura, e de outra obra do mesmo autor Obrazy z dějin národa českého (Retratos da História da Nação Boémia), datada de 1939-1940, combinando aspectos de ambos os textos numa narrativa distinta. ${ }^{22} \mathrm{~A}$ escolha de obras de Vančura não parece ter sido casual, tendo em conta o seu notório percurso político e artístico: reputado membro do partido comunista, embora expulso do mesmo em 1929 por se opor à então nova direcção stalinista, foi assassinado pelos nazis em 1941, em resposta à execução de Heydrich em Praga, o que the granjeou o estatuto de mártir. Além disso, foi uma das figuras de proa do grupo modernista Devětsil (Nove Forças), impulsionador do Poetismo.

Este movimento, circunscrito à Checoslováquia, preconizava a transformação da lingua em arte visual (poema pictórico), perfilhando a crença de que o cinema, a novíssima arte, poderia ser o medium privilegiado para salvar uma sociedade em crise (Winner, 2015: 43-64). Guiado por estes princípios na concepção do romance e tendo sido ele próprio realizador de cinema, Vančura determinará algumas das opções tomadas na adaptação cinematográfica de ML: uma insistência no visualismo e no poder sugestivo da imagem, a associação pictórica por contraste com uma narrativa linear e uma ordem estritamente causal, bem como pela adopção de diferentes pontos de vista na narração, os quais geram uma ambiguidade sobre quem vê e como o vê (realidade, sonho, devaneio, memória, visão miraculosa). Podemos dar como exemplo do que acabamos de dizer a cena em que Mikoláš persegue

21. A ideia de tornar transparente a realidade medieval manifesta-se também em alguns filmes históricos franceses dos anos 70, como sucede com Lancelot du Lac, de Robert Bresson (1974), ou Perceval le Gallois, de Erich Rohmer (1978). Ambos procuraram adaptar obras literárias medievais, nomeadamente os textos de Chrétien de Troyes, fazendo uma releitura do texto integral de forma a mostrar as condições naturalmente duras e austeras «desse tempo». Esta concepção de cinema também é inerente a outros filmes históricos, nomeadamente o filme de Sergei Parajanov, A Cor das Romãs (1969), que retrata a vida e a obra do poeta-trovador arménio do século XVIII, Sayat-Nova.

22. No entanto, Vlácil também se deixou influenciar pela literatura medieval: não apenas no uso frequente de símbolos, mas também no recurso a epígrafes que acompanham o desenrolar do filme e vão situando o espectador na história contada, já que formalmente elas remetem de forma muito clara para a titulação de capítulos da literatura e historiografia medievais, começando muitas das vezes com a fórmula «de como», para não falar do uso de letra gótica (combinada, é certo, com um tipo de letra moderno) nas mesma epígrafe. 
Christian von Hennau, na qual a câmara adopta a perspectiva de Mikoláš (uma técnica que hoje parecerá menos surpreendente a uma parte do público, por se encontrar amiúde em videojogos first person, como Counterstrike ou Minecraft). ${ }^{23}$

Numa cena inicial do filme em que intercepta Lazar inspecionando a caravana do conde alemão atacada pelos Kozlik, Mikoláš ordena a Lazar que reze, como que num gesto preliminar a matá-lo. À medida que a oração avança, o rosto vai-se iluminando e, no momento em que Lazar evoca a sua filha, Marketa, temos uma transição de imagem: primeiro o espectador vê um convento no cimo de um morro, para onde convergem varias freiras com pombas nas mãos; em seguida surge Marketa, correndo na direção da câmara, também com uma pomba, que, ao contrário das freiras, traz parcialmente escondida sob o vestido, entre os seios, havendo aqui uma nova transição, sugerindo a entrega da pomba à abadessa do convento. Esta sequência é intercalada com frames de Lazar e Míkolaš, de forma

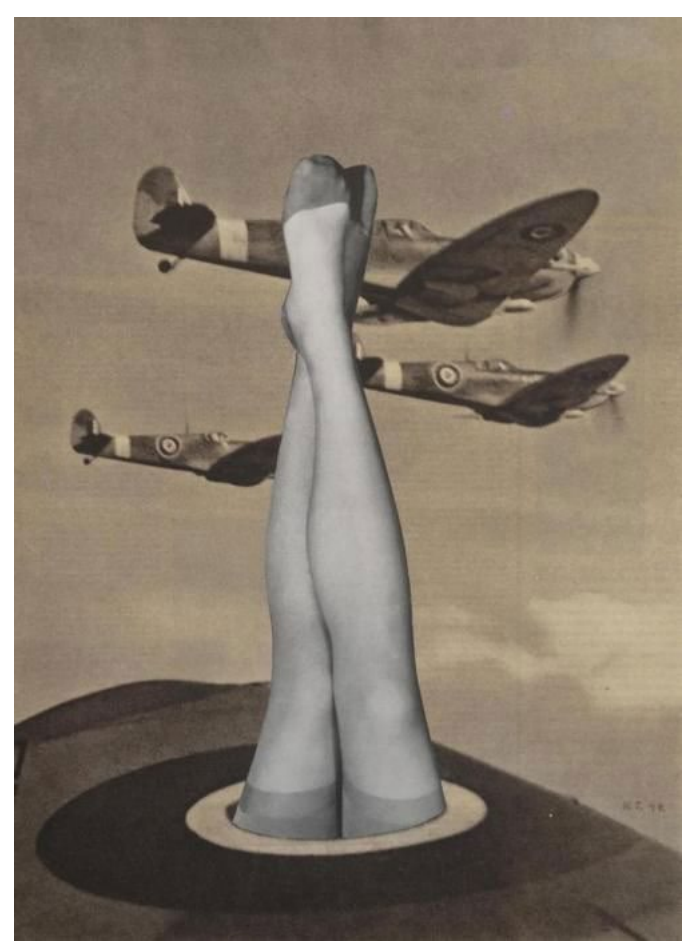

Karel Teige, Untitled, 1947 que se torna ambíguo se a «visão» é ou não partilhada por ambos.

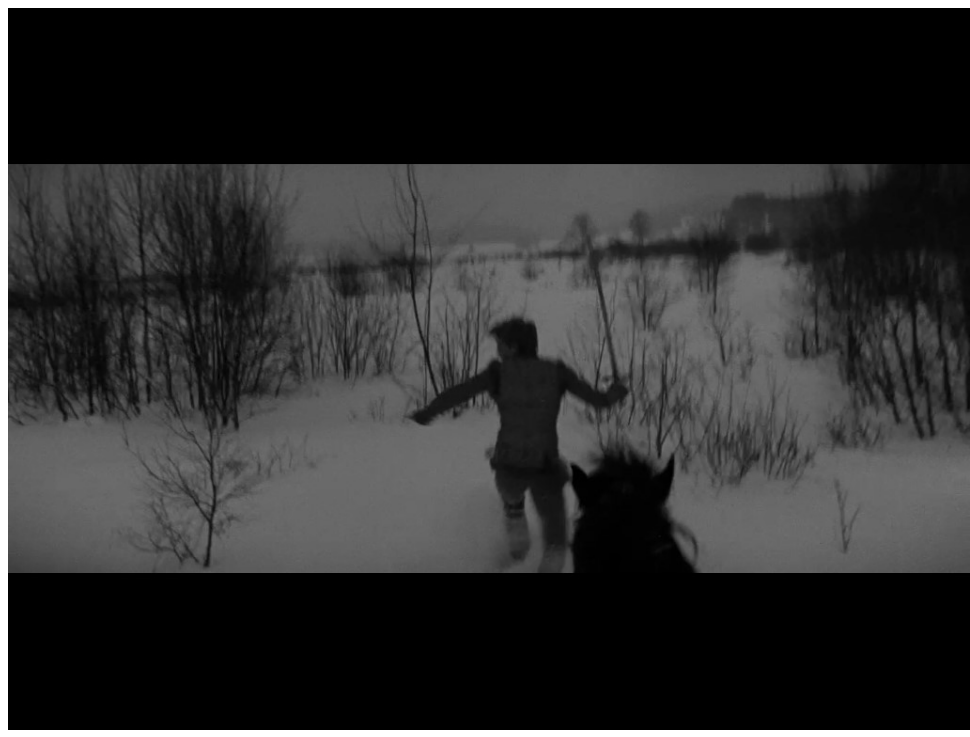

Marketa Lazarová

23. Abel Gance, um dos mestres do movimento Impressionista francês utiliza esta técnica no seu único filme histórico, Napoléon vu par Abel Gance (1927) (Thompson e Bordwell, 2019: 80). 

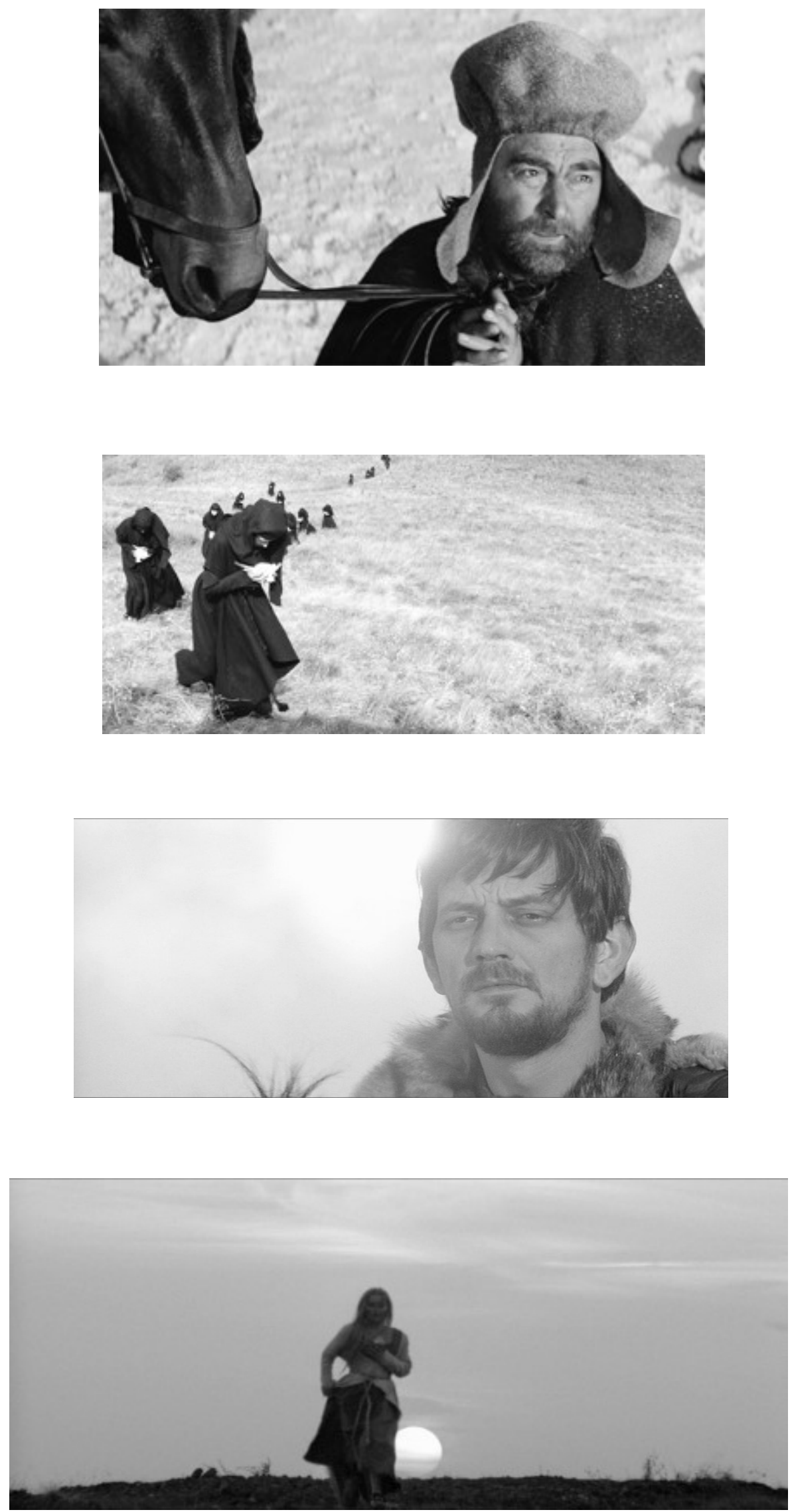

Marketa Lazarová 
Em todo o caso, é na sequência desta visão que Mikoláš decide poupar a vida de Lazar, o que será determinante para o enredo, além de simbolicamente importante, pois, como fica claro pelo diálogo, já em Roháček, entre Kozlik e Mikoláš, tal gesto, bem como o simples facto de ter permitido a Lazar a oração, contradiz o ethos guerreiro do clã, o qual, ao longo de todo o filme, oscila entre uma postura «pagãı» e uma cristã, sugerindo que os Kozlik são, de algum modo, «entidades em transição», subsistindo numa espécie de limbo entre dois mundos, em vez de claramente num só.

Todos estes procedimentos ilustram como o filme não pretende oferecer uma verdade explícita e total, mas sim tingida de subjectividade e dispersa em alusões, envolta numa obscuridade que exige do espectador uma participação activa na construção de sentido. Essa parece ser, aliás, a ideia expressa pelas estranhas palavras que introduzem o filme:

\title{
TOT̄ PŘ İ́ĒH SESTAVENȲ MÁLEM ZBỦHDARMA
}

A STĚží zasLOUŽí Si CHVÁLU.

COŽ NAPLAT.

\section{PROUTEK PROUTKAR̆ŮV SE STÁLE OHÝBÁ} NAD TËMITO SPODNÍMI VODAMI.

Marketa Lazarová

\author{
Este relato foi composto praticamente ao acaso \\ e mal chega a ser digno de nota. \\ Não importa. \\ A vara do vedor continua a vibrar \\ sobre as águas que se ocultam por baixo.
}

Longe de o situarem inequivocamente em coordenadas espácio-temporais (e morais) definidas, como de resto é habitual no cinema histórico americano, e como também sucede em AN, esta legenda introdutória "explica», obliquamente, por associação, em jeito de parábola (forma discursiva também abundante na ldade Médiapor influência bíblica), o conceito que Vláčil tem de cinema «histórico».

Além de introduzir uma ligação explícita ao seu primeiro «filme histórico», Dáblova past, já que em nenhum outro momento em ML ocorre qualquer tipo de alusão ou referência à prospecção de água, ${ }^{24}$ condensa também um aspecto bastante «medieval», no sentido em que o mundo circundante confronta os indivíduos com uma multiplicidade confusa de símbolos, que subverte a narrativa do filme histórico no modelo de Hollywood (linear) e

24. É impossível não ver neste filme o contraste entre o curso inexorável, impassível da natureza (inclusive a natureza humana), a atitude de leitura atenta dos seus sinais por oposição à atitude crente do clérigo. Também aqui há uma ambiguidade, pois se o conflito entre a atitude «científica» do moleiro e a atitude dogmática do clérigo parece encaixar no cânone socialista, por outro lado podemos também entrever, naquela figura, o perfil do «oficial», que se dirige às massas já munido de uma verdade pré-definida, que dispensa «interpretações». 
também no modelo do realismo socialista («progressista»). E se, por um lado, o último, como o vemos corporificado em AN, é mais «medievalı na medida em que se centra na representação de comportamentos a imitar e a evitar, numa moral exemplarista e didáctica, por outro, a linearidade "progressista» é o seu elemento propriamente moderno, que o aproxima mais da primeira avant-garde, apesar do que os separa, como veremos em maior detalhe no «epílogo» deste texto. Quando o narrador de ML, logo na abertura do filme, profere as palavras (que não fazem parte do romance de Vančura): «as coisas mais antigas jazem na teia do tempo presente $\|^{25}$ assume uma perspectiva que é em espírito mais «materialista» do que a própria abordagem oficial do regime, como a observação de Němec acerca dos dolly shots já permite constatar.

De facto, ao longo de todo o filme, a sugestão e a ambiguidade deixam entrever a autonomia das personagens face ao narrador, ao mesmo tempo que permitem aos espectadores formar a sua própria visão sobre a narrativa (maior liberdade, diversidade de perspectivas acerca do mundo). É nisto que reside o carácter eminentemente político da arte cinematográfica de Vláčil: ao assumir que a verdade ou a Perspectiva Justa sobre a realidade não pode ser conferida por um ditame, vindo de cima, mas é conquistada pelo próprio sujeito, através da observação, tal como em Ďáblova past o moleiro interpreta a natureza pela observação empírica atenta, por contraste com o dogmatismo do sacerdote jesuíta (o apparatchik?), cujos olhos estão fixos, como o próprio afirma, no Céu e não na Terra. A história, como o enredo de $M L$, que espelha a complexidade caótica das experiências subjectivas (mas não menos reais) que o compõem, não se apresenta com uma «chave de leitura» pronta, a que um grupo exclusivo de intérpretes iluminados (um politburo) tenha um acesso especial (uma doutrina que nunca se questiona). A chave de leitura tem de ser obtida pela observação, a partir das inevitáveis limitações de perspectiva de cada observador, procurando superá-las. E aqui é talvez sugerida, implicitamente, uma imagem do que o socialismo deveria ser (deixando de parte a questão de poder sê-lo): participação activa na construção de sentido, em vez de recepção passiva de uma cartilha. Porém, nada disto é simplesmente dado ao espectador; é um caminho que ele é convocado a fazer por si - precisamente como o vedor que observa e interpreta os sinais da natureza.

Em suma, as estratégias cinematográficas que temos vindo a observar em ML estão ausentes no filme (embora este juízo não se estenda, evidentemente, à obra) de Eisenstein, Alexander Nevsky, no qual a câmara adopta um ponto de vista estável, único, e, quando recorre a grandes planos de rostos, fá-lo explicitamente, de forma a destacar figuras antagónicas (recorde-se: mostrar sem ambiguidades o que se deve imitar e o que não se deve, o positivo e o negativo). Aqui não há uma uespreitadela»; tudo é explícito, obedecendo muito mais de perto aos cânones do realismo socialista. No entanto, como vimos, há também fissuras neste aparente triunfo da ordem estabelecida. 


\section{Conclusão}

A Idade Média de Eisenstein e a Idade Média de Vláčil diferem entre si, na medida em que também a sociedade soviética na década de 1930 e a sociedade checoslovaca na década de 1960 diferem entre si. Como divergem esteticamente é uma questão dificilmente inteligível se abstrairmos do contexto de produção e do que Eisenstein, Vláčil e as pessoas que trabalharam com eles realizaram, dadas as nossas melhores conjecturas sobre o que procuraram realizar, nos contextos em que o fizeram. Neste sentido, e esperamos que a nossa análise contextual dos filmes torne isso mais claro, podemos talvez dizer que no cinema, mais claramente do que sucede nas outras artes (embora também nelas), não podemos compreender ou avaliar cabalmente o valor estético, nem mesmo o dos aspectos ditos «formais», por uma perspectiva formalista, que reduza o valor estético apenas ao directamente visível ou audível.

Vimos isto claramente com a introdução de informação acerca de um possível contacto, directo ou indirecto, de Eisenstein com fontes manuscritas medievais. Mesmo as possibilidades de leitura dos aspectos formais sai enriquecida com a ampliação do background sobre o qual novas qualidades estéticas do todo podem subitamente tornar-se visiveis. $O$ que poderiam parecer aspectos mais directamente políticos, determinados pela necessidade pragmática do momento, abrem-se a uma leitura mais abrangente e matizada, como a da representação dos cavaleiros teutónicos com a iconografia associada a poetas da tradição germânica medieval. Podemos também dizer que um processo inverso se verifica a propósito de aspectos aparentemente «apolíticos» num filme inequivocamente inscrito na Nova Vaga checoslovaca. Ambos os filmes aqui analisados procuram encontrar resposta ao modo de entender a relação entre o poder do estado, o clã, a tribo, a horda, a agressão, a guerra, a figura do outro e do inimigo. O primeiro é simultaneamente arte e propaganda, e corresponde ao estado socialista em fase de consolidação, explorando e reafirmando os mitos que servem à legitimação política das suas acções perante a ameaça externa e interna, e o seu enraizamento numa grande narrativa de progresso. O outro surge num contexto de uma tentativa de desconstrução desta ordem social já consolidada. Aqui, o poder régio, ou poder político central, é a figura dúbia, e os aristocratas-bandidos que vivem à margem deste poder, agarrando-se feroz e precariamente ao seu modo de existência, têm uma posição mais central, numa narrativa a que é difícil atribuir claramente um centro, onde nada está claramente dividido entre bem e mal, luz e trevas, positivo e negativo. Formam também dois modelos de relação entre a política e a violência, usando representações da Idade Média para falar acerca do presente, seja ou não esse o seu propósito declarado.

Formalmente, ambos os filmes que analisámos são de uma enorme beleza, mas a diferença fundamental está na valência política dessa beleza. Porém, o mais flagrante contraste entre AN e ML será talvez que o primeiro se esforça por mostrar o poder político como algo belo. Em ML, é a beleza impassível do mundo natural que confronta o caos e a desordem das relações humanas. Tal contraste exprime também uma dualidade no interior do projecto da 
avant-garde no século XX: por um lado, o ataque de Dada ao culto da beleza artística como forma de hipocrisia política; por outro, a estetificação da guerra (Benjamin, 2003:42) e do poder no futurismo. Esta foi também a batalha intelectual travada pelos cineastas da Nova Vaga checoslovaca, bem como de outros movimentos de renovação do cinema em vários países do Bloco de Leste no mesmo período, e.g. a Vaga Negra jugoslava. Foi uma batalha travada em resposta a uma sociedade que venerava a beleza do ideal socialista ao mesmo tempo que permanecia cega, indiferente à amargura que espalhava. A injustiça de uma geração moldada pela guerra e os seus traumas impondo a uma outra geração as balizas possíveis de toda a experiência humana, mais do que qualquer consideração sobre a natureza do socialismo como regime político. Como o futurismo, o realismo socialista era uma arte da guerra, para a guerra. As «novas vagas» da década de 1960 têm algo da energia de Dada (nuns mais evidentemente que noutros, como em Chytilova), a sua posição fundamentalmente moral e política, de fazer «guerra à guerra», mas são também algo fundamentalmente novo, ou diferente.

\section{Filmografia}

Alexandre Nevsky (Serguei Eisenstein, 1938).

Greve (Serguei Eisenstein, 1925).

Outubro (Serguei Eisenstein, 1927).

O Couraçado Potemkine (Serguei Eisenstein, 1925).

Marketa Lazarová (František Vláčil, 1967).

O Vale das Abelhas (František Vláčil, 1967).

A Armadilha do Diabo (František Vláčil 1962).

Os Nibelungos (Fritz Lang, 1924).

Shadows of Forgotten Ancestors (Serguei Pajaranov, 1969). 


\section{Bibliografía}

\section{Manuscrita}

Codex Manesse, UB Heidelberg, Cod. Pal. germ. 848.

\section{Impressa}

ArnheIM, Rudolf (1957), Film as Art, Berkeley, University of California Press.

Bartig, Kevin (2017), Sergei Prokofiev's Alexander Nevsky, Oxford, Oxford University Press.

Bauer, Thomas (2018), Warum es kein islamisches Mittelalter gab. Das Erbe der Antike und der Orient, Munique, C. H. Beck .

Benjamin, Walter (2003), Das Kunstwerk im Zeitalter seiner technischen Reproduzierbarkeit, Berlim, Suhrkamp. BERGER, John (1972), Ways of Seeing, London, Penguin.

Branco, Sérgio Dias (2020), O trabalho das imagens. Estudos sobre cinema e marxismo, Lisboa, Página a Página.

EISENSTEIN, Sergei (2004), Problems of filmmaking, Honolulu, University of Pacific Press.

GetTY, J. Arch (2013), Practicing Stalinism: Bolsheviks, Boyars and the Persistence of Tradition, Yale, Yale University Press.

Groys, Boris (1992), The Total Art of Stalinism: Avant-Garde, Aesthetic Dictatorship, and Beyond, trad. Charles Rougle, Princeton, Princeton University Press.

GunNING, Tom (2013), "Cinema of the Wolf: The Mystery of Marketa Lazarováy), Criterion.

Hames, Peter (1985), «František Vláčil», em The Czechoslovak New Wave, Berkeley, University of California Press, pp. 37-44.
Hames, Peter (2005), «Marketa Lazarován, em The Cinema of Central Europe, Nova lorque, Wallflower Press, pp. 151-161.

Hames, Peter (2009), Czech and Slovak Cinema - Theme and Tradition, Edinburgo, Edinburgh University Press. Hames, Peter (2014), «Alienated Heroes: Marxism and the Czechoslovak New Wavely, em Marx at the Movies. Revisiting History, Theory and Practice, eds. Ewa Mazierska e Lars Kristensen, Londres, Palgrave Macmillan, pp. 147170.

Hames, Peter (2018), «The Czech New Wave revisited», em 1968 and Global Cinema, eds. Christina Gerhardt e Sara Saljoughi, Detroit, Wayne State University Press, pp. 77-94.

HAYDOCK, Nickolas (2009), «Homeland Security: Northern Crusades through the East-European Eyes of Alexander Nevsky and the Nevsky Traditionı, em Hollywood in the Holy Land, eds. Nickolas Haydock e E. L. Risden, Jefferson (Carolina do Norte), McFarlane, pp. 47-92.

LaKoff, George e Mark Johnson (1980), Metaphors We Live By, Chicago e Londres, University of Chicago Press.

Le Goff, Jacques (2014), Faut-il vraiment découper l'histoire en tranches?, Paris, Le Seuil.

LIEHM, Antonín J. (2016/1974), Closely Watched Films: the Czechoslovak Experience, Londres, Routledge.

O' Mahony, Mike (2008), Sergei Eisenstein, Reaktion Books.

OAKESHOTT, Ewart (1999), The Archaeology of Weapons Arms and Armour from Prehistory to the Age of Chivalry, Woolbridge, Boydell Press.

Ostrowskı, Donald (2006), «Alexander Nevskii's "Battle on the Ice": the 
creation of a legend», Russian History, ThOMPSON, Kristin e David BordWell (2019), 33.2/4, pp. 289-312. Film History: An Introduction. Nova PANOFSKY, Erwin (1977), «Style and lorque, McGraw-Hill (quarta edição). Medium in the Motion Picturesı em VANCURA, Vladislav (2016), Marketa Aesthetics: a Critical Anthology, orgs. Lazarová, (tradução de Carleton George Dickie e Richard Sclafani, Bulkin), London, Twisted Spoon Press. Nova Iorque, St. Martin's Press, pp. WILDE, Oscar, Intentions (1905), The 351-365.

Decay of Lying, Pen Pencil and Poison,

Pater, Walter (1980), The Renaissance: The Critic as Artist. The Truth of Masks, Studies in Art and Poetry, Berkeley, Nova lorque, Brentano's.

University of California Press.

Winner, Thomas G. (2015), The Czech

SavignaC, David (ed.) (2016), 3rd

Chronicle of Pskov, Crofton, Beowulf Avant-Garde Literary Movement and Sons.

Between the World Wars, eds. Ondrej Sládek e Michael Heim, Londres e SONTAG, Susan (1977), On Photography, Nova lorque, Peter Lang.

Nova Iorque, Picador, Farrar, Straus \&

Giroux. 
Gomes, Joana y Vitor Guerreiro, ulmagens da Idade Média em Alexander Nevsky e Marketa Lazarová: algumas considerações estéticas e históricas», Storyca 2 (2021), pp. 105-132.

https://doi.org/10.51863/Storyca.2021.GomesyGuerreiro

\section{Resumen}

No século XX, fenómenos como a arte de massas - em particular o cinema - surgem concomitantemente a novas formas de relação entre poder político, ideologia, arte e estética. Com a Revolução Russa de 1917, e, mais tarde, os regimes fascistas que se espalham pela Europa, a alternância entre a experimentação estética arrojada e o arregimentar da arte à propaganda tornam-se realidades que, de um ou outro modo, impõem aos artistas alguma forma de posicionamento. Neste processo, é frequente as representações do passado servirem para possibilitar um certo discurso acerca do presente, sobretudo quando as representações directas deste se tornam "politicamente problemáticas»" (i.e. perigosas). Tal é o que sucede com o próprio conceito de Idade Média, desde a sua origem. Este artigo pretende justamente explorar o modo como as representações cinematográficas da Idade Média servem diferentemente de veículo à de expressão de concepções estéticas, artísticas e políticas em dois filmes produzidos em países do ex-bloco socialista, onde as tensões e alternâncias de que falamos se tornam, mais do que uma questão meramente teórica, uma questão de sobrevivência: Alexander Nevsky de Serguei Eisenstein (1938) e Márketa Lazarová de František Vláčil (1967).

\section{Abstract}

In the 20th century, phenomena like that of mass art - particularly cinema- emerge in tandem with new forms of relationship between political power, ideology, art and aesthetics. With the Russian Revolution of 1917, and, later, with the spread of fascist regimes across Europe, alternating between bold aesthetic experimentation and the use of

\section{Palavras chave}

Cinema

Idade Média

Sergei Eisenstein

František Vláčil

\section{KeyWords}

Cinema

Middle Ages

Sergei Eisenstein

František Vlácil 
art as propaganda become factors that compel artists, in one way or another, to take some sort of stand. In this process, representations of the past are often employed so as to make it possible to speak about the present, especially when direct portrayal of the latter becomes 'politically problematic' (i.e. dangerous). Such is also the case with the concept of 'middle ages' itself, from its inception. Our aim in this paper is precisely to explore how representations of the middle ages serve, in different ways, as a vehicle for the expression of aesthetic and political views, in two films made in countries of the former socialist bloc, where the tensions and shifting pressures we mentioned become, more than a purely theoretical issue, a matter of survival: Sergei Einsenstein's Alexander Nevsky (1938) and František Vláčil's Márketa Lazarová (1967). 